\title{
PERFORMANCE OF PROMISING HYBRID RICE GENOTYPES UNDER DIFFERENT IRRIGATION INTERVALS
}

\author{
E. E. Gewaily, H. Sh. Hamad, B. B. Mikhael and E. F. Arafat \\ Rice Research Department, Field Crops Research Institute, \\ Agricultural Research Center, Egypt.
}

Received: Jan. 17, 2021

Accepted: Jan. 26,2021

\begin{abstract}
Water shortage stress is the most critical abiotic factor reducing rice yield. Water deficit stress at whichever of the rice critical growth stage causes decline in yield. A field experiment was conducted at the Experimental Farm of Sakha Agricultural Research Station, Kafrelsheikh, Egypt during 2018 and 2019 seasons, to investigate the effect of four irrigation intervals (continuous flooding(11), irrigation every six days(12), nine days(I3) and twelve days(14)) on performance of five genotypes (Giza 178, IR 69625A/Giza 178, IR 70368A/Giza 178, IR 69625A/Giza 179 and IR 69625A/Giza 181). Strip plot design, with four replications was used. The horizontal plots were assigned to irrigation treatments, while the vertical plots were assigned to rice genotypes. Different drought tolerance indices such as abiotic tolerance index (ATI), stress susceptibility index (SSI), mean productivity (MP), tolerance index (TOL) and stress susceptibility percentage index (SSPI) were tested in screening superior rice genotypes. The results showed that days to $\mathbf{5 0} \%$ heading, plant height, panicle length, panicle weight, number of effective tillers hill $^{-1}$, spikelet's number panicle ${ }^{-1}$, number of branches panicle ${ }^{-1}$, seed set (\%), 1000-grain weight $(\mathrm{g})$, number of filled grains panical ${ }^{-1}$, grain yield $\mathrm{t}^{\text {ha }}{ }^{-1}$, harvest index (\%) and biomass weight $\mathrm{t} \mathrm{ha}^{-1}$ were highly significantly affected by the interaction between irrigation intervals and genotypes. The highest values of grain yield were obtained by IR69625A/Giza 181 under continuous flooding irrigation during both seasons. Based on results of different drought tolerance indices, IR69625A/Giza 181 showed lowest values of ATI, SSI and TOL and the highest values of MP and SSPI and was identified as drought tolerant genotype.
\end{abstract}

Key words: Rice genotypes, irrigation intervals, drought tolerance indices and grain yield.

\section{INTRODUCTION}

Rice (Oryza sativa L.) is one of the foremost staple food crops for nearly sixty five percentage of the world's population. Therefore, sustainable rice production is necessary to overcome food scarcity throughout the globe. However, rice is considered one of the most drought-sensitive plants due to its small root system, thin cuticular wax, and swift stomatal closure (Ji et al., 2012). Water shortage is the prime environmental constrictions, which happen in many parts of the world annually, habitually having destructive effects on crops productivity. Thus, drought mitigation, through development of drought-tolerant varieties with higher yields suitable for water-limiting environments, will be the key factor to improve stable rice production (Kumar et al., 2016). Water deficiency is one of the most limiting factors in more than $30 \%$ of paddy fields in Egypt, consequently improving varieties tolerating water shortage is one of the most important objectives in rice breeding programs (Abd Allah, 2010). Stomata closing, leaf area reduction, thicker cuticles, roots enlargement, maintaining photosynthetic rates at high levels, producing or rising the rate of some proteins, regulating the 
osmotic conditions, accumulation of organic acids, changes in carbohydrate metabolism and dropping the rate of respiration are the typical biochemical and physiological drought tolerance mechanisms in rice plant ( $\mathrm{Ji}$ et al., 2012 and Sahebi et al., 2018). Choice the right and proper genotypes on the basis of relative yield performance has been considered a reliable method for evaluating a large number of genotypes in water deficits stressed conditions (Panthuwan et al., 2002). Kumar et al., (2016) stated that the traits include plant height, days to flowering, delay in flowering, grain yield panicle ${ }^{-1}$, biomass/biological yield, harvest index, number of panicles plant $^{-1}$, panicle length, panicle excretion, spikelet fertility, total number of spikelets, panicle length, 1000-grain weight and seed setting. They are all affected by different intensities of drought stress under field conditions.

Numerous selection indices founded on a mathematical relative between grain yield under water deficits stressed and non-stressed conditions have been proposed. The capability of improved genotypes to perform reasonably well in drought stressed environments is vital for stability or increase the production. The combination of high yield stability and high relative grain yield under waters stress has been proposed as helpful selection criteria for characterizing genotypic performance under varying degrees of water shortage stress (Gaballah, 2018 and Adhikari et al., 2019). The improvement of drought tolerance genotypes with a optimum yield prospective is one of the major aims of drought tolerance rice breeding for enhancing rice production in Egypt. On the other hand, with the end of the twenty-first century, the drop of water resources as a result of anthropogenic and natural factors will lessen the intense consumer of water (Joshi et al., 2016).
There are various indices to ascertain drought tolerance such as stress tolerance level (TOL), stress tolerance index (STI), stress susceptibility index (SSI) and stress susceptibility percentage index (SSPI), which may be helpful as an indicator for identifying drought tolerant genotypes that do well in stressful environments. These indices are yield stability parameters which are based on the amount of reduction are achieved under stress of water deficiency condition (Kumar et al., 2014 and Adhikari et al., 2019). Raman et al., (2012) stated that rice genotypes which achieved minimal yield reduction had the lowest SSI and TOL values. Various researchers stated that the varieties which had the minimum SSI values were drought tolerant than the varieties which had the maximum SSI values. Application indices of drought tolerance in the select of drought tolerant genotypes have been statement in several crops (Sio-Se Mardeh et al., 2006 and Kumar et al., 2014).

The purpose of present study was to identify promising hybrid rice genotypes having optimum yield potential and stability under water deficit stress conditions and recognize the most suitable drought yield indices to understanding of yield changes by water stress and irrigated conditions.

\section{MATERIALS AND METHODS}

A field experiment was conducted during the two consecutive rice growing seasons 2018 and 2019 at the Experimental Farm of Sakha Agricultural Research Station, Kafrelsheikh, Egypt. The experiment was conducted to assess the performance of four promising hybrid rice genotypes beside Giza 178 rice (as inbred cultivar) under different irrigation intervals. The previous crop was barely (Hordeum Vulgare L.) in the two seasons. The soil of the investigational site is 
clayey in texture. The initial soil chemical properties (soil analysis according Cottenie et al., 1982) at 0 to $20 \mathrm{~cm}$ soil depth of the investigational site as an average of both seasons were: $\mathrm{pH} \mathbf{8 . 2}$, organic matter (OM) $1.5 \%$, total nitrogen $685 \mathrm{mg} \mathrm{kg}^{-1}$, available $\mathrm{P} 11 \mathrm{mg} \mathrm{kg}^{-1}$, available $\mathrm{K} 370 \mathrm{mg} \mathrm{kg}^{-1}$, available $\mathrm{Zn}$ $0.73 \mathrm{mg} \mathrm{kg}^{-1}$, available Fe $5.45 \mathrm{mg} \mathrm{kg}^{-1}$ and

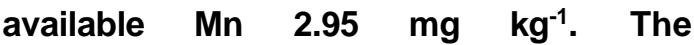
experimental design was strip plot with four replications. The horizontal plots were assigned to four irrigation treatments namely, continuous flooding (11), irrigation every six (12), nine (13) and twelve days (14), while the vertical plots were assigned to different genotypes i.e., Giza 178 as inbred rice cultivar and four promising hybrid genotypes IR 69625A/Giza 178, IR 70368A/Giza 178, IR 69625A/Giza 179 and IR 69625A/Giza 181.

Seeds at the level of $24 \mathrm{~kg} \mathrm{ha}^{-1}$ for promising hybrid genotypes and at the level of $144 \mathrm{~kg} \mathrm{ha}^{-1}$ for Giza 178 were soaked in water for $24 \mathrm{hr}$, and then incubated for $48 \mathrm{hr}$ to accelerate early germination. Pre-germinated seeds were uniformly broadcasted in the nursery on $8^{\text {th }}$ and $5^{\text {th }}$ May of the two seasons, respectively. The permanent field was well prepared, i.e. plowed twice followed by well dry leveled. Basal application of phosphorus and potassium fertilizers was applied to all plots and incorporated well into the soil during land preparation at the rate of $36 \mathrm{~kg} \mathrm{P}_{2} \mathrm{O}_{5}$ and $60 \mathrm{~kg} \mathrm{~K} \mathrm{~K}_{2} \mathrm{O}$ per hectare using single super phosphate fertilizer and potassium sulfate, respectively. Nitrogen fertilizer was applied at the rate of $165 \mathrm{~kg} \mathrm{~N} \mathrm{ha}^{-1}$ in the form of urea $(46.5 \% \mathrm{~N})$. Urea was added in three equal splits, as basal application, and top dressed at 35 and 70 days after transplanting. All other agronomic practices were done as recommended. Seedlings were carefully uprooted from the nursery at 30 days after sowing and distributed in the plots. Seedlings were manually transplanted in $20 \times 20 \mathrm{~cm}$ space between rows and hills, with 1 seedling hill-1.
Number of days to $50 \%$ heading was recorded for each genotypes. At harvest, the plant height $(\mathrm{cm})$ and number of effective tillers hill $^{-1}$ were estimated. Ten panicles were collected randomly to estimate the panicle length $(\mathrm{cm})$, panicle weight (g), number of branches panicle ${ }^{-1}$, number of filled grains panicle ${ }^{-1}$, and 1000 -grain weight $(\mathrm{g})$. The crop of central $5 \mathrm{~m}^{2}$ of each plot was harvested separately at full maturity, dried, threshed, then grain and straw yields were recorded and each of them was converted into $\mathrm{t} \mathrm{ha}^{-1}$. The grain yield was modified at $14 \%$ moisture content.

Drought tolerance evaluations were estimated as follow:

1-Abiotic tolerance index (ATI) according to Moosavi et al., (2008).

$$
A T I=\left[\left(Y_{p}-Y_{s}\right) /\left(\overline{\mathrm{Y}}_{\mathrm{p}} / \overline{\mathrm{Y}}_{\mathrm{s}}\right)\right] *\left[\sqrt{Y_{p}^{*} Y_{s}}\right]
$$

2-Stress susceptibility index (SSI) assesses the reduction in yield caused by unfavorable (stress) compared to favorable irrigated environments (Raman et al., 2012).

$$
S S I=\frac{1-\left(\frac{\dot{Y}_{S}}{Y_{P}}\right)}{1-\left(\frac{\bar{Y}_{S}}{\bar{Y}_{P}}\right)}
$$

3- Mean productivity (MP) the differences in yield between the stress and nonstress environments (Hossain et al., 1990 and Kumar et al., 2014). $\mathrm{MP}=\left(\mathrm{Y}_{\mathrm{P}}+\mathrm{Y}_{\mathrm{S}}\right) / 2$

4- Tolerance index (TOL) the difference in yield and the average yield between stress and non-stress environments (Rosielle and Hambling, 1981).

$\mathrm{TOL}=\mathrm{Y}_{\mathrm{P}}-\mathrm{Y}_{\mathrm{S}}$

5- Stress susceptibility percentage index (SSPI) (Moosavi et al., 2008).

Where:

$$
\operatorname{SSPI}=\left[\frac{Y_{p}-Y_{s}}{2\left(\bar{Y}_{\mathrm{p}}\right)}\right] * 100
$$

$Y_{P}=$ the potential grain yield under continues flooding

$Y_{S}=$ the grain yield under irrigation treatment

$Y_{P}=$ Mean grain yield under continues flooding

$Y_{s}=$ Mean grain yield under stress continue 
Data were statistically analyzed according to Gomez and Gomez (1984). The mean differences were compared by the Duncan's Multiple Range Test (Duncan, 1955) using a statistical computer package CoStat. Correlation analysis was computed by following the standard statistical procedure by Steel et al., (1997).

\section{RESULTS AND DISCUSSION}

Results in Table (1) showed that days to heading $50 \%$, as well as plant height and number of effective tillers hill $^{-1}$ at harvest were significantly affected by irrigation intervals. The number of days to $50 \%$ heading significantly increased by increasing irrigation intervals. The differences in heading dates could be attributed to the extended vegetative stage due to water stress. Lafitte et al., (2004) and Mohamed et al., (2019) stated that water deficit stress results in delay heading, this is mainly due to a reduction in plant dry matter production and slowed elongation of the panicle and supporting tissues and therefore delay panicle exsertion. Plant height and number of effective tillers hill $^{-1}$ were decreased as intervals period increased up to 12 days, in both seasons. The reduction in plant height could be attributed to reduction in cell turger that causes reduction in cell enlargement, which in turn decreases shoots enlargement. Ahmed et al., (2017) reported that water stress situation has a high influence on plant growth and results in the reduction of plant height. Water stress reduces the cell size and cell division, which may affect the plant height under drought condition. However, the reduction in number of effective tillers hill ${ }^{-1}$ could be attributed to less ability of tiller nodes to produce more tillers under water stress. A similar trend was found by Sarvestani et al., (2008), El-Refaee et al., (2012) and Gewaily et al., (2019).

Table 1. Effect of irrigation intervals on plant characteristics of different genotypes during 2018 and 2019 seasons.

\begin{tabular}{|c|c|c|c|c|c|c|}
\hline \multirow{2}{*}{ Treatment } & \multicolumn{2}{|c|}{ Days to $50 \%$ heading } & \multicolumn{2}{|c|}{ Plant height (cm) } & \multicolumn{2}{|c|}{$\begin{array}{c}\text { Number of effective } \\
\text { tillers } \text { hill }^{-1}\end{array}$} \\
\hline & 2018 & 2019 & 2018 & 2019 & 2018 & 2019 \\
\hline Irrigation interval (I) & & & & & & \\
\hline I1 & 93.66d & 94.18d & $89.70 a$ & $90.67 a$ & $25.60 a$ & $25.87 a$ \\
\hline 12 & 95.37c & 95.47c & 87.60b & 88.47b & $24.27 a$ & $24.33 b$ \\
\hline 13 & $96.53 \mathrm{bc}$ & $96.65 b$ & $84.58 c$ & $86.40 \mathrm{c}$ & $22.73 b$ & $22.80 \mathrm{c}$ \\
\hline 14 & $97.92 \mathrm{a}$ & $97.86 a$ & $82.25 c$ & 83.18d & $20.00 c$ & $20.80 d$ \\
\hline F test & * & * & ** & ** & ** & ** \\
\hline Genotype (G) & & & & & & \\
\hline Giza 178 & 93.24de & 93.24d & $87.07 b c$ & $88.59 b$ & $21.08 \mathrm{c}$ & $21.50 c$ \\
\hline IR 69625A/Giza 178 & $95.33 c$ & 95.92c & $85.58 \mathrm{c}$ & $89.92 a$ & 23.17ab & $22.58 b c$ \\
\hline IR 70368A/Giza 178 & $96.83 b c$ & $97.42 \mathrm{bc}$ & 83.94d & $84.08 \mathrm{~cd}$ & $24.08 a$ & $24.17 a$ \\
\hline IR 69625A/Giza 179 & $92.32 \mathrm{e}$ & $91.57 e$ & $81.51 e$ & 82.91d & $22.84 b$ & $23.67 \mathrm{ab}$ \\
\hline IR 69625A/Giza 181 & $101.64 a$ & $102.08 \mathrm{a}$ & $92.07 a$ & $90.40 \mathrm{a}$ & $24.59 a$ & $25.34 a$ \\
\hline F test & ** & ** & ** & ** & * & * \\
\hline$I \times G$ & ** & ** & ** & ** & ** & ** \\
\hline
\end{tabular}

$I_{1}=$ Continuous flooding, $I_{2}=$ irrigation every 6 days, $I_{3}=$ irrigation every 9 days and $I_{4}=$ irrigation every 12 days

* = Significant at 0.05 level, $* *=$ Significant at 0.01 level and NS= Not significant

Means in the same column designated by the same letter are not significantly different at $5 \%$ level 
Rice genotypes varied significantly in number of days to $50 \%$ heading, plant height and number of effective tillers

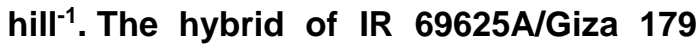
was earlier in heading time than other genotypes while, hybrid of IR 69625A/Giza 181 was later in heading and produced the tallest plants and the highest number of effective tillers hill $^{-1}$ in both seasons.

Table (2) exhibited that the highest period needed to $50 \%$ heading was obtained by IR 69625A/Giza 181when irrigated every12-day. While IR 69625A/Giza 179 under continuous irrigated recorded the lowest period needed to $50 \%$ heading in both seasons. These findings are in close agreement with those reported by Gaballah (2009).
Heading delay is a common drought response observed in rice (EL-Refaee et al. (2005), which is expected to confer a benefit in those environments where water deficit stress is impermanent, if development and flowering resume after the stress is relieved. The delays in heading and maturity might be considered as good indicators in drought screening tests because the effect of drought on the trait was consistent (Mohamed et al., 2019). IR 69625A/Giza 181with continue irrigated produced the tallest plants and the highest number of effective tillers hill ${ }^{-1}$. While IR 69625A/Giza 179 gave the shortest plants and the lowest number of effective tillers hill $^{-1}$ when irrigated every12-day.

Table 2. Days to $50 \%$ heading, plant height and number of effective tillers hill-1as affect by the interaction between genotypes and irrigation intervals during 2018 and 2019 seasons.

\begin{tabular}{|c|c|c|c|c|c|c|c|c|}
\hline \multirow{3}{*}{ Genotype } & \multicolumn{4}{|c|}{2018} & \multicolumn{4}{|c|}{2019} \\
\hline & I1 & 12 & 13 & 14 & I1 & 12 & 13 & 14 \\
\hline & \multicolumn{8}{|c|}{ Days to $50 \%$ heading } \\
\hline Giza 178 & $89.29 \mathrm{e}$ & $93.67 d$ & 94.33d & $95.67 \mathrm{c}$ & $90.66 f$ & 92.33ef & $94.60 d$ & 95.35d \\
\hline IR 69625A/Giza 178 & 93.33d & 94.30d & $96.00 \mathrm{c}$ & 97.67cd & $94.00 \mathrm{de}$ & $95.00 d$ & $96.67 \mathrm{~cd}$ & $98.00 \mathrm{bc}$ \\
\hline IR 70368A/Giza 178 & $95.00 \mathrm{~cd}$ & $96.33 c$ & 97.66c & 98.33c & $96.00 \mathrm{~cd}$ & 97.33cd & $97.67 \mathrm{~cd}$ & $98.67 \mathrm{bc}$ \\
\hline IR 69625A/Giza 179 & $90.67 e$ & $91.29 \mathrm{e}$ & 92.67d & 94.64d & 89.59f & 91.35ef & 91.67ef & 93.66d \\
\hline IR 69625A/Giza 181 & $100.00 \mathrm{bc}$ & $101.27 a b$ & 102.00ab & $103.27 a$ & $100.67 \mathrm{abc}$ & $101.33 a$ & $102.66 a$ & 103.64a \\
\hline \multicolumn{9}{|c|}{ Plant height (cm) } \\
\hline Giza 178 & $90.67 b$ & $88.66 b$ & $85.33 c$ & 83.61cd & $91.00 \mathrm{~b}$ & $90.67 b$ & $89.00 b c$ & 83.67d \\
\hline IR 69625A/Giza 178 & $90.33 b$ & 86.31bc & 83.01cd & $82.68 \mathrm{~cd}$ & $93.67 a$ & $90.00 \mathrm{~b}$ & $89.00 \mathrm{bc}$ & 87.00c \\
\hline IR 70368A/Giza 178 & $87.83 b$ & $86.00 \mathrm{bc}$ & $82.59 \mathrm{~cd}$ & 79.32d & $85.00 \mathrm{~cd}$ & $84.00 d$ & 82.00de & 80.64ef \\
\hline IR 69625A/Giza 179 & 83.67c & $82.67 \mathrm{~cd}$ & $81.65 \mathrm{~cd}$ & $78.05 d$ & 89.00b & $85.33 \mathrm{~cd}$ & 83.00de & $79.00 f$ \\
\hline IR 69625A/Giza 181 & $96.00 \mathrm{a}$ & $94.38 a$ & $90.30 \mathrm{~b}$ & 87.58b & $94.67 a$ & $92.33 a$ & 89.00b & $85.59 c$ \\
\hline \multicolumn{9}{|c|}{ Number of effective tillers hill-1 } \\
\hline Giza 178 & $23.00 \mathrm{c}$ & 22.33d & 21.00de & $18.00 f$ & $23.33 \mathrm{~cd}$ & 22.00de & 21.67e & 19.00ef \\
\hline IR 69625A/Giza 178 & $25.67 b$ & 24.33bc & 22.66d & $20.00 \mathrm{e}$ & $25.00 \mathrm{bc}$ & $24.00 c$ & $21.33 e$ & 20.00ef \\
\hline IR 70368A/Giza 178 & $26.00 \mathrm{a}$ & 25.33b & $24.00 \mathrm{bc}$ & 21.00de & 26.67a & $25.00 \mathrm{bc}$ & 23.67c & $21.33 e$ \\
\hline IR 69625A/Giza 179 & $25.67 b$ & $23.67 \mathrm{bc}$ & $22.00 \mathrm{~d}$ & $20.00 \mathrm{e}$ & $26.00 \mathrm{~b}$ & $24.67 \mathrm{bc}$ & $23.00 \mathrm{c}$ & $21.00 \mathrm{e}$ \\
\hline IR 69625A/Giza 181 & $27.67 a$ & $25.67 a$ & 24.00b & 21.00de & $28.35 a$ & $26.00 \mathrm{~b}$ & 24.33c & 22.67de \\
\hline
\end{tabular}

$\mathrm{I}_{1}=$ Continuous flooding, $\mathrm{I}_{2}=$ irrigation every 6 days, $\mathrm{I}_{3}=$ irrigation every 9 days and $\mathrm{I}_{4}=$ irrigation every 12 days

Means in the same column designated by the same letter are not significantly different at $5 \%$ level 
Results in Table (3) indicated that yield attributes i.e., panicle length, panicle weight, number of branches panicle $^{-1}$, number of spikelets panicle ${ }^{-1}$, number of filled grains panicle ${ }^{-1}$, seed set (\%) and 1000-grain weight were significantly affected by irrigation intervals. They were reduced as off period increased up to 12-days, in both seasons. The highest values of all traits were obtained with continuous flooding followed by irrigation every 6-day. These results are in agreement with those stated by Gewaily et al., (2019) who stated that such increment in yield attributes under non stress condition could be due to that reality available water enhanced the biological and physiological process which increase the production and translocation of the dry matter content from source to sink which resulting in more panicles, grain filling and weight. These results are in harmony with those stated by El-Refaee et al., (2005) and Zubaer et al. (2007).

Results in Table (3) revealed that a significant difference was obtained among tested genotypes in respect of yield attributes traits i.e., panicle length, panicle weight, number of branches panicle $^{-1}$, number of spikelets panicle ${ }^{-1}$, number of filled grains panicle ${ }^{-1}$, seed set (\%) and 1000-grain weight in both seasons. Also, the results showed that IR 69625 A/Giza 181 produced the highest values of panicle length, panicle weight, number of branches panicle ${ }^{-1}$, number of spikelets panicle ${ }^{-1}$, number of filled grains panicle ${ }^{-1}$, compared to the other rice genotypes in both seasons. On the other hand, Giza 178 produced the lowest values of panicle length, panicle weight, number of branches panicle ${ }^{-1}$, number of spikelets panicle ${ }^{-1}$, number of filled grains panicle ${ }^{-1}$ and 1000-grain weight. Most variation among the rice genotypes in yield attributes traits might be due to the genetic background differences.
Interaction between irrigation intervals and rice genotypes significantly affected the panicle length, panicle weight, number of spikelets panicle ${ }^{-1}$, number of filled grains panicle ${ }^{-1}$, seed set (\%) and 1000 -grain in both seasons. Results in Table (4) indicated that the tested hybrid rice genotypes produced the highest values under contiuous flooding treatment, while the lowest values were recorded with irrigation every 12-day. These results are in harmony with those stated by Zaman et al. (2018) who reported that drought stress caused several constructional and functional disruptions in reproductive organs, leading to malfunction of fertilization or premature abortion of the seed. Early senescence, shortens the grain fillness period, photosynthesis reduction and enhanced soluble sugars remobilization from grains to other vegetative parts are observed when water stress happens at the reproductive stage. The sugars or carbohydrate remobilizations strongly depend on source activity and sink strength which vary with genotypes.

Results in Table (5) revealed that prolonging irrigation intervals caused a reduction in the grain yield. Continuous flooding recorded the highest biomass and grain yield followed by irrigation every 6-day. The reduction in biomass yield as affected by prolonging the irrigation intervals may be due to the decrease in dry matter production, plant height and number of effective tillers hill- $^{-1}$. However, the reduction in grain yield as affected by prolonging the irrigation intervals may be attributed to the reduction in dry matter production, panicle weight, number of panicles hill-1, number of filled grains panicle $^{-1}$ and 1000-grain weight. A similar trend was found by El-Refaee et al. (2012) and Gewaily et al. (2019), who found that continuous flooding gave the highest grain yield. Also, the irrigation every 


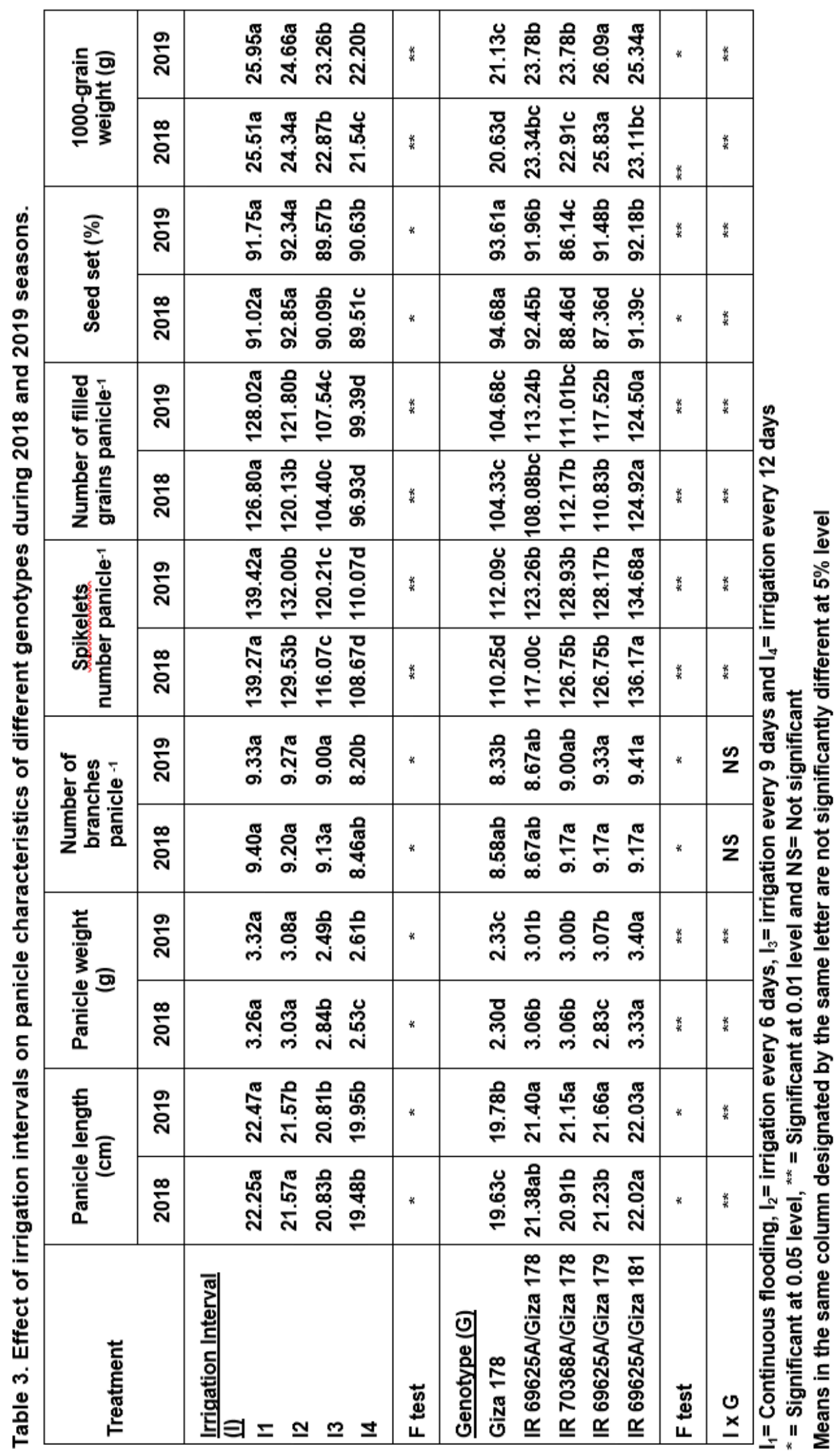




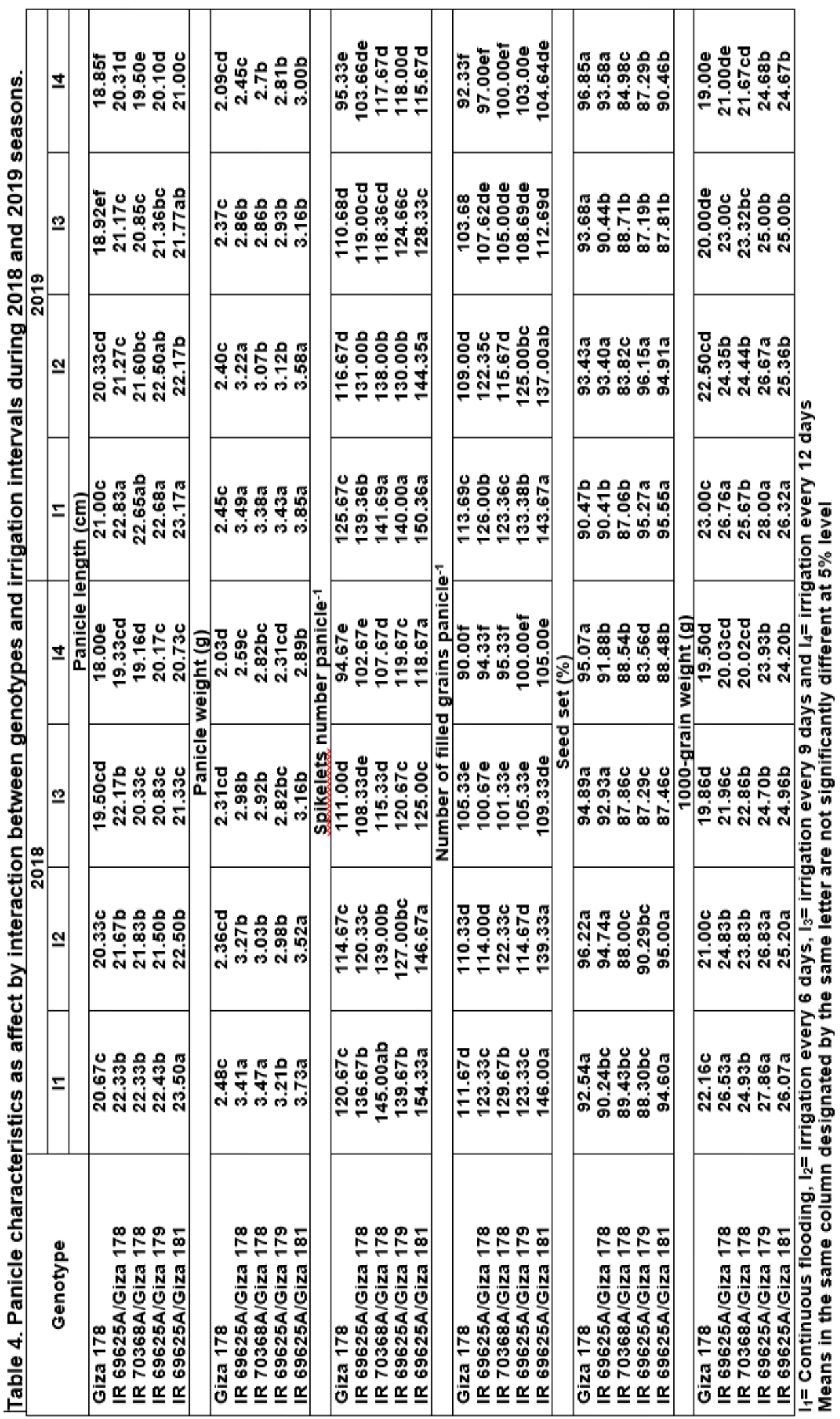


Table 5. Effect of irrigation intervals on biomass yield $\left(\mathrm{t} \mathrm{ha}{ }^{1}\right)$, grain yield (t ha ${ }^{1}$ ) and harvest index (\%) of different genotypes during 2018 and 2019 seasons.

\begin{tabular}{|l|c|c|c|c|c|c|}
\hline \multirow{2}{*}{ Treatment } & \multicolumn{2}{|c|}{ Biomass yield (t ha $\left.{ }^{1}\right)$} & Grain yield (t ha ${ }^{1}$ ) & \multicolumn{2}{c|}{ HI (\%) } \\
\cline { 2 - 7 } & 2018 & 2019 & 2018 & 2019 & 2018 & 2019 \\
\hline Irrigation Interval (I) & & & & & & \\
I1 & $25.37 \mathrm{a}$ & $25.98 \mathrm{a}$ & $11.25 \mathrm{a}$ & $11.19 \mathrm{a}$ & $44.84 \mathrm{a}$ & $44.74 \mathrm{a}$ \\
I2 & $23.42 \mathrm{~b}$ & $23.39 \mathrm{~b}$ & $10.59 \mathrm{~b}$ & $10.62 \mathrm{~b}$ & $44.71 \mathrm{a}$ & $44.11 \mathrm{a}$ \\
I3 & $20.95 \mathrm{c}$ & $20.92 \mathrm{c}$ & $9.46 \mathrm{c}$ & $9.34 \mathrm{c}$ & $43.52 \mathrm{~b}$ & $43.74 \mathrm{~b}$ \\
I4 & $19.22 \mathrm{~d}$ & $19.13 \mathrm{~d}$ & $8.64 \mathrm{~d}$ & $8.47 \mathrm{~d}$ & $44.34 \mathrm{ab}$ & $43.54 \mathrm{~b}$ \\
\hline F test & $*$ & $*$ & $* *$ & $* *$ & $*$ & $*$ \\
\hline Genotype (G) & & & & & & \\
Giza 178 & $18.84 \mathrm{~d}$ & $18.72 \mathrm{~d}$ & $8.86 \mathrm{~d}$ & $8.84 \mathrm{~d}$ & $46.86 \mathrm{a}$ & $47.01 \mathrm{a}$ \\
IR 69625A/Giza 178 & $23.08 \mathrm{~b}$ & $23.13 \mathrm{~b}$ & $10.39 \mathrm{ab}$ & $10.10 \mathrm{~b}$ & $43.20 \mathrm{c}$ & $42.84 \mathrm{c}$ \\
IR 70368A/Giza 178 & $23.28 \mathrm{~b}$ & $23.05 \mathrm{~b}$ & $10.36 \mathrm{~b}$ & $10.30 \mathrm{~b}$ & $43.82 \mathrm{~b}$ & $44.06 \mathrm{~b}$ \\
IR 69625A/Giza 179 & $20.94 \mathrm{c}$ & $21.17 \mathrm{c}$ & $9.45 \mathrm{c}$ & $9.43 \mathrm{c}$ & $44.74 \mathrm{~b}$ & $44.09 \mathrm{~b}$ \\
IR 69625A/Giza 181 & $25.06 \mathrm{a}$ & $25.71 \mathrm{a}$ & $10.90 \mathrm{a}$ & $10.87 \mathrm{a}$ & $43.16 \mathrm{c}$ & $42.17 \mathrm{~d}$ \\
\hline F test & $* *$ & $* *$ & $* *$ & $* *$ & $*$ & $*$ \\
\hline I X G & $* *$ & $* *$ & $* *$ & $* *$ & NS & NS \\
\hline
\end{tabular}

$\mathrm{I}_{1}=$ Continuous flooding, $\mathrm{I}_{2}=$ irrigation every 6 days, $\mathrm{I}_{3}=$ irrigation every 9 days and $\mathrm{I}_{4}=$ irrigation every 12 days

* = Significant at 0.05 level, ** = Significant at 0.01 level and NS= Not significant

Means in the same column designated by the same letter are not significantly different at $5 \%$ level

6-day was statistically placed in the same level with flooded method. This might be due to better growth characters (dry matter, chlorophyll content and plant height) associated with higher mobility and absorption of mineral nutrients in soil solution, which enhanced the uptake of nutrients and contributed to favorable growth attributes consequently, resulted in production higher yield.

Results in Table (5) also, showed that the differences in genotypes were highly significant for biomass yield and grain yield in both seasons. The hybrid 69625A/Giza 181 gave the highest values of biomass weight and grain yield while, the lowest values of grain yield and biomass weight were obtained with the genotype of Giza 178. On the other hand, the genotype Giza 178 gave the highest values of harvest index. While, the hybrid 69625A/Giza 181 gave the lowest values of harvest index in 2018 and 2019 seasons.

The results in Table (6) indicated that the interaction between genotypes and irrigation intervals was significantly affected biomass yield and grain yield in both seasons. The combination between IR 69625A/Giza 181 with continuous flooding produced the highest values of grain yield and biomass weight. While, the lowest values of biomass weight and grain yield were obtained with Giza 178 when irrigated every 12-day in 2018 and 2019 seasons. The results are inconformity with that stated by Kondhia et al., (2015).

\section{Drought yield indices:}

The data in Table (7) showed that the drought yield indices abiotic tolerance index (ATI), stress susceptibility index (SSI) and tolerance index (TOL) gave the same trend approximately for different genotypes where, the drought 
susceptible genotypes were resulted the highest values of ATI, SSI and TOL in contrast to this, the drought tolerance genotypes were recorded the lowest values of ATI, SSI and TOL. A similar trend was found by Singh et al., (2018) and Adhikari el al., (2019) who reported that TOL and SSI are useful parameters for identifying genotypes that perform well in stress situation and the genotypes with low values can be considered as drought tolerant. On the other hand, the drought yield indices mean productivity (MP) and stress susceptibility percentage index (SSPI) gave the same trend for all genotypes therefore, the drought susceptible genotypes recorded the lowest values of MP and SSPI as well as the drought tolerance genotypes were recorded the highest values of MP and SSPI. The results were observed is agreement with Kumar et al., (2014) and Kondhia et al., (2015).

Results in Table (7) showed that genotype of IR 69625A/Giza 181 under different irrigation intervals had the lowest values of ATI, SSI and TOL. While, genotype of IR 69625A/Giza 178 gave the highest values of ATI, SSI and TOL under different irrigation intervals. On the other hand, the highest values of MP and SSPI attained from the IR 69625A/Giza 181. With respect to MP the genotype of Giza 178 gave the lowest values while, the lowest values of SSPI were obtained with IR 69625A/Giza 178 under different irrigation intervals. According the results IR 69625A/Giza 181 was more tolerant to drought stress because it had the lowest values of ATI, SSI and TOL and the highest values of MP and SSPI (Table 7). The results are in harmony with Singh et al., (2018) and Adhikari el al., (2019) who reported that TOL index was effective in improving yield of genotypes under condition of water shortage stress and the chosen genotypes performed poorly under non-stressed condition. Gaballah, (2018) reported that use of SSI in blend with yield value under water deficiency stress condition for discovering drought tolerant/sensitive genotypes.

Table 6. Effect of interaction between genotypes and irrigation intervals on biomass ( $\mathrm{t} \mathrm{ha}^{-1}$ ) and grain yield $\left(\mathrm{t} \mathrm{ha} \mathrm{h}^{-1}\right.$ ) during 2018 and 2019 seasons.

\begin{tabular}{|c|c|c|c|c|c|c|c|c|}
\hline \multirow{3}{*}{ Genotype } & \multicolumn{4}{|c|}{2018} & \multicolumn{4}{|c|}{2019} \\
\hline & I1 & 12 & 13 & 14 & I1 & 12 & 13 & 14 \\
\hline & \multicolumn{8}{|c|}{ Biomass yield (t ha') } \\
\hline Giza 178 & $21.50 \mathrm{~d}$ & $19.94 \mathrm{e}$ & $17.76 f$ & $16.15 \mathrm{~g}$ & $21.04 \mathrm{e}$ & $20.02 e$ & $17.26 f$ & $16.55 \mathrm{~g}$ \\
\hline IR 69625A/Giza 178 & $27.43 b$ & $23.56 \mathrm{~cd}$ & 21.64de & $19.68 \mathrm{e}$ & $27.60 \mathrm{~b}$ & 22.94d & $21.37 e$ & $20.59 \mathrm{e}$ \\
\hline IR 70368A/Giza 178 & $25.32 b c$ & $24.55 \mathrm{c}$ & $22.60 d$ & $20.63 e$ & $25.75 b c$ & $24.63 \mathrm{~cd}$ & 22.30de & $19.50 f$ \\
\hline IR 69625A/Giza 179 & 22.79d & $22.00 d$ & $20.28 e$ & $18.70 f$ & $23.92 \mathrm{~cd}$ & 22.18de & $20.29 e$ & $18.29 f$ \\
\hline IR 69625A/Giza 181 & $29.79 a$ & $27.07 b$ & $22.46 d$ & $20.93 e$ & $31.61 \mathrm{a}$ & $27.17 b$ & 23.37c & $20.70 \mathrm{e}$ \\
\hline \multicolumn{9}{|c|}{ Grain yield (t ha-1) } \\
\hline Giza 178 & $10.27 \mathrm{c}$ & 9.73d & $8.56 \mathrm{e}$ & $6.89 f$ & $10.22 b c$ & $9.69 c$ & 8.44 & $7.00 f$ \\
\hline IR 69625A/Giza 178 & $11.74 a$ & 11.12b & $9.86 \mathrm{e}$ & $8.75 e$ & $11.58 \mathrm{a}$ & $10.97 b$ & $9.50 \mathrm{c}$ & 8.34d \\
\hline IR 70368A/Giza 178 & $11.71 \mathrm{a}$ & $10.95 \mathrm{c}$ & $9.72 \mathrm{e}$ & $9.05 e$ & $11.51 \mathrm{a}$ & $10.88 b$ & $9.61 \mathrm{c}$ & $9.19 \mathrm{~cd}$ \\
\hline IR 69625A/Giza 179 & $10.73 \mathrm{c}$ & 9.93d & $8.67 e$ & $8.48 \mathrm{e}$ & $10.65 b$ & $10.07 c$ & 9.04d & 7.95ed \\
\hline IR 69625A/Giza 181 & $11.81 \mathrm{a}$ & $11.21 b$ & $10.62 d$ & $10.02 d$ & $12.00 \mathrm{a}$ & $11.94 a$ & $10.12 \mathrm{c}$ & $9.86 \mathrm{c}$ \\
\hline
\end{tabular}

$\mathrm{I}_{1}=$ Continuous flooding, $\mathrm{I}_{2}=$ irrigation every 6 days, $\mathrm{I}_{3}=$ irrigation every 9 days and $\mathrm{I}_{4}=$ irrigation every 12 days

Means in the same column designated by the same letter are not significantly different at $5 \%$ level 


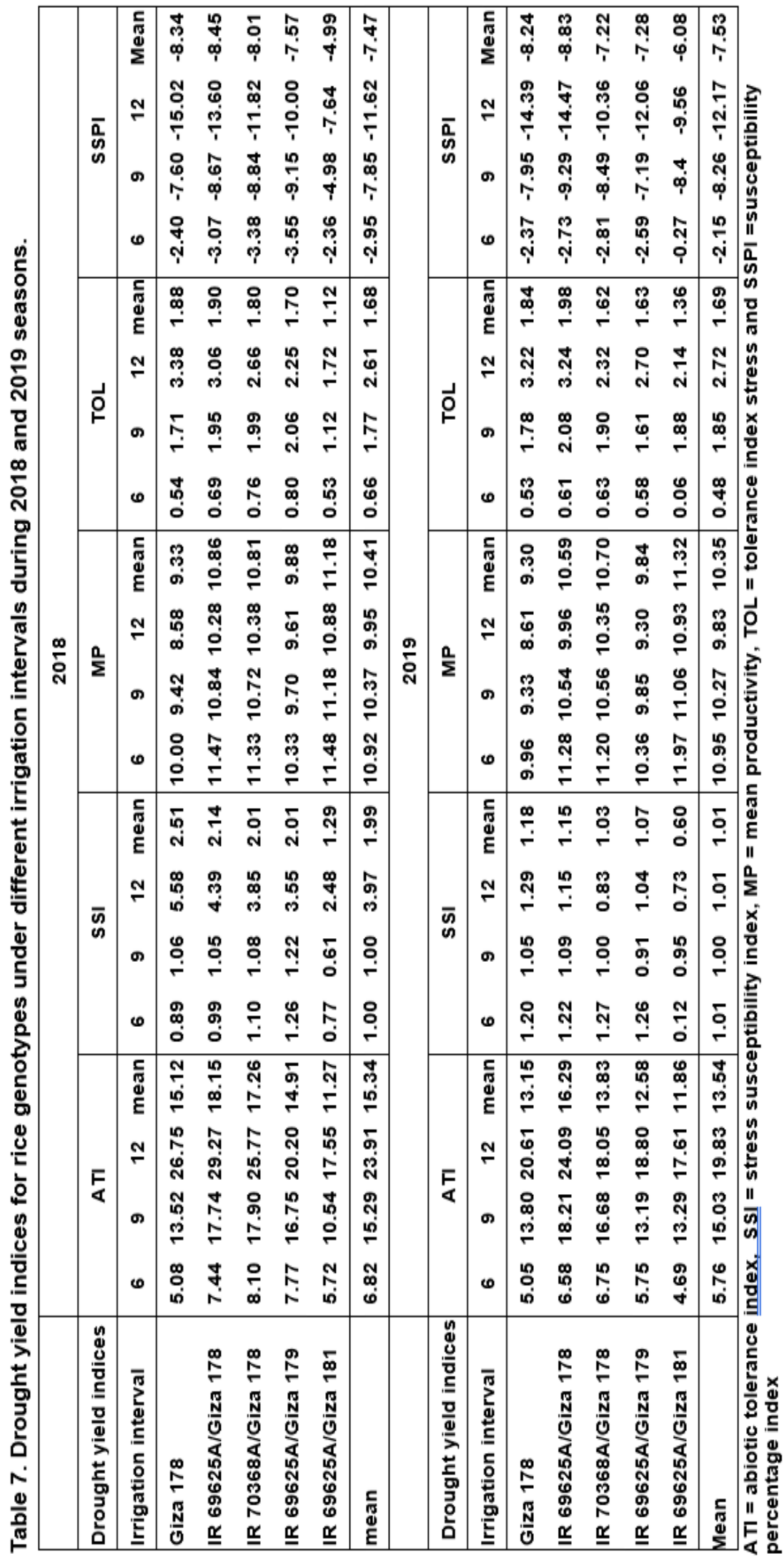




\section{Correlation among grain yield and drought tolerance indices}

Correlation coefficients were used to find the best criterion for choosing drought tolerant genotypes. According to literature (Kumar et al., 2014 and Gaballah, 2018), the appropriate index must to have a significant relationship with yield in both stressed (irrigation every 12 days) and non-stressed (continuous flooding) conditions. As shown in Table (8) the potential grain yield $\left(Y_{P}\right)$ under continuous flooding was highly significant and positive correlated with grain yield under stress $\left(Y_{12}\right)$ conditions. Also $Y_{P}$ and $Y_{12}$ were also highly significantly and positively associated with drought indices MP and SSPI and they were closely related together. Otherwise, the highly significant and negative correlation was found among ATI, SSI and TOL with grain yield under both conditions. On the other hand, MP and SSPI were significantly and negatively correlated with ATI, SSI and TOL. In addition positive correlation was observed among ATI, SSI and TOL. Similar results were stated by Gaballah and AbdAllah (2015) and Mau et al., (2019) who reported that drought indices having a significant correlation with grain yield in both non-stressed and stressed conditions are reported to be suitable for selecting drought tolerant genotypes.

Table 8. Correlation between drought yield indices studied

\begin{tabular}{|c|c|c|c|c|c|c|c|}
\hline & Yp & $\mathrm{Y}_{12}$ & ATI & SSI & MP & TOL & SSPI \\
\hline Yp & 1 & & & & & & \\
\hline Y12 & $0.90^{\star *}$ & 1 & & & & & \\
\hline ATI & -0.12 & $-0.51^{* *}$ & 1 & & & & \\
\hline SSI & $-0.69^{\star *}$ & $-0.92^{* *}$ & $0.78^{\star *}$ & 1 & & & \\
\hline MP & $0.96^{* *}$ & $0.99^{* *}$ & $-0.37^{*}$ & $-0.85^{* *}$ & 1 & & \\
\hline TOL & $-0.52^{\star *}$ & $-0.84^{* *}$ & $0.87^{* *}$ & $0.96^{* *}$ & $-0.73^{* *}$ & 1 & \\
\hline SSPI & $0.52^{* *}$ & $0.84^{* *}$ & $-0.87^{* *}$ & $-0.96^{* *}$ & $0.73^{* *}$ & $-1.00^{* *}$ & 1 \\
\hline
\end{tabular}

$Y_{p}=$ the potential grain yield under continues flooding $Y_{12}=$ the grain yield under irrigation every 12 days

$\mathrm{ATI}=$ abiotic tolerance index, $\mathrm{SSI}=$ stress susceptibility index, MP = mean productivity, TOL = tolerance index stress and SSPI =susceptibility percentage index

\section{CONCLUSION}

Egypt suffers from a shortage of available water, so rice researchers are striving to develop varied genotypes that are tolerant to the long irrigation period. The investigation was conducted to assess the performance of some promising hybrid rice genotypes under different irrigation intervals and recognize the most suitable drought yield indices. According the results assessed from various parameters of drought tolerance indices, it revealed that, promising hybrid rice of IR 69625A/Giza 181 gave the highest grain yield under different irrigation intervals and has lowest values of ATI, SSI and TOL and the highest values of MP and SSPI thus it was the most tolerant for stress of prolong irrigation period.

\section{REFERENCE}

Abd Allah A. A. (2010). Development of some high yielding rice lines tolerant to drought stress conditions. J. Medicinal Plants Research. 4(7): 528535.

Adhikari, M., N. Adhikari, S. Sharma, J. Gairhe, R. Bhandari and S. Paudel (2019). Evaluation of drought tolerant rice cultivars using drought tolerant indices under water stress and 
irrigated condition. American J. of Climate Change. 8(2): 228-236.

Ahmed, M., Md. Ehsanul Haq, Md. Monir Hossain, Md. Shefat-al-Maruf and M. M. Hasan (2017). Performance of four different rice cultivars under drought Stress in the North-Western Part of Bangladesh. International J. Agric. and Forestry. 7(6): 134-139.

Cottenie, A., P. M. Verloo, L. Kiekens, G. Velghe and R. Camerlynek (1982). Chemical Analysis of Plants and Soils. Lab. Anal. Agrochem. State Univ., Gent. Belgium.

Duncan, D. B. (1955). Multiple range and multiple F test. Biometrics, 11: 1- 42.

El-Refaee I. S., A. E. Abd-El-Wahab and S. A. Ghanem (2005). Physiological performance and yield of some rice cultivars as affected by different irrigation intervals. Egypt J. Agric. Res., 83(58): 393-410.

El-Refaee, I. S., R. N. Gorgy and T. F. Metwally (2012). Response of some rice cultivars to plant spacing for improving grain yield and productivity under different irrigation intervals. Alex. J. Agric. Res., 57(1): 1-15.

Gaballah, M. M. and A. A. AbdAllah (2015). Effect of water irrigation shortage on some quantitative characters at different rice development growth stages. World Rural Observations. 7(2):10-21.

Gaballah, M.M. (2009). Studies on physiological and morphological traits associated with drought resistance in rice (Oryza sativa L.). PhD thesis. Kafrelsheikh University.

Gaballah, M. M. (2018). Agronomical traits and drought tolerance indices for some rice genotypes under drought stress and non-stress conditions. Proceeding of The $7^{\text {th }}$ Field Crops Research Institute Conference 18-19 Dec. 149-164.
Gewaily, E. E., Amera T. Mohammed and W. T. Abd El-Rahem (2019). Effect of different irrigation regimes on productivity and cooking quality of some rice varieties. W JA S 15 (5): 341-354.

Gomez, K. A. and A. A. Gomez (1984). Statistical Procedures for Agricultural Research.2 ${ }^{\text {nd }}$ Edition, John Wiley and Sons, New York.

Hossain, A. B. S., R. G. Sears, T. S. Cox and G. M. Paulsen (1990). Desiccation tolerance and its relationship to assimilate partitioning in winter wheat. Crop Sci., 30:622-627.

Ji, K., Y. Wang and W. Sun (2012). Drought-responsive mechanisms in rice genotypes with contrasting drought tolerance during reproductive stage. J. Plant Physiology. 169(4): 336-344.

Joshi, R., S. H. Wani, B. Singh, A. Bohra, Z. A. Dar, A. A. Lone, A. Pareek and S. L. Singla-Pareek (2016). Transcription factors and plants response to drought stress: current understanding and future directions, Front. Plant. Sci. 7, 1029,1-15.

Kondhia, A., R. E. Tabien and A. Ibrahim (2015). Evaluation and selection of high biomass rice (Oryza sativa L.) for drought tolerance. Amer. J. of Plant Sci., 6: 1962-1972.

Kumar A., S. Basu, V. Ramegowda and A. Pereira (2016). Achieving sustainable cultivation of rice. Mechanisms of drought tolerance in rice. Burleigh Dodds Science Publishing Limited, (1) :1-34.

Kumar S., S. K. Dwivedi, S. S. Singh, S. K. Jha, S. Lekshmy, R. Elancheian, O. N. Singh and B. P. Bhatt (2014). Identification of drought tolerant rice genotypes by analysing drought tolerance indices and morphophysiological traits. SABRAO J. 
Breeding and Genetics. 46 (2): 217230.

Lafitte H. R., A. Ismail and J. Bennett (2004). Abiotic stress tolerance in rice for Asia: progress and the future. In Proceeding of $4^{\text {th }}$ International Crop Science Congress, Brisbane, Australia. 26: 1137.

Mau, Y. S., Ndiwa, A. S. S., Oematan, S. S. and J. E. R. Markus (2019). Drought tolerance indices for selection of drought tolerant, high yielding upland rice genotypes. Australian J. Crop Science 13 (1): 170-178.

Mohamed A., S. Sedeek, A. Galal and M. Alsakka (2019). Effect of water deficiency as abiotic stress on the reproductive and ripening stage of rice genotypes. Int. J. Plant Sci. Agric. 2(1):13-19.

Moosavi S. S., B. Y. Samadi, M. R. Naghavi, A. A. Zali, H. Dashti and A. Pourshahbazi (2008). Introduction of new indices to identify relative drought tolerance and resistance in wheat genotypes. Desert 12: 165-178.

Panthuwan, G., S. Fokai, M. Cooper, S. Rajatasereekul and J. C. Toole (2002). Yield response of rice genotypes to different types of drought under rainfed lowlands. Part 1: grain yield and yield components. Field Crop Res. 41: 45-54.

Raman, A., S. Verulkar, N. P. Mandal, M. Varrier, V. D. Shukla, J. L. Dwivedi, B. N. Singh, O. N. Singh, P. Swain, A. K. Mall, S. Robin, R. Chandrababu, A. Jain, T. R. Ram, S. Hittalmani, S. Haefele and A. Kumar (2012). Drought yield index to select high yielding rice lines under different drought stress severities. 5lfh:5(31): 1-12.

Rosielle, A. A. and J. Hamblin (1981). Theoretical aspects of selection for yield in stress and non-stress environment. Crop Sci. 21: 943-946.
Sahebi, M., M. M. Hanafi, M. Y. Rafii, T. M. Mahmud, P. Azizi, M. Osman, R. Abiri, S. Taheri, N. Kalhori, M. Shabanimofrad, G. Miah, and N. Atabaki (2018). Improvement of drought tolerance in rice (Oryza sativa L.): genetics, genomic tools, and the WRKY gene family. BioMed Research International. 1-20.

Sarvestani, Z. T., H. Pirdashti, S. A. M. M. Sanavy, and H. Balouchi (2008). Study of water stress effects in different growth stages on yield and yield components of different rice (Oryza sativa L.) cultivars, Pak. J. Biol. Sci. PJBS, 11(10): 1303-1309.

Singh, S. P., A. Kumar, A. Satyendra, M. Kumar, S. Nahakpam, S. Sinha, H. Smrity, P. Sundaram, S. Kumar and P. $K$. Singh (2018). Identification of drought tolerant rice (Oryza sativa L.) genotypes using drought tolerance Indices under Normal and Water Stress Condition. International Journal of Current Microbiology and Applied Sciences. 7: 4757-4766.

Sio-Se Mardeh, A., A. Ahmadi, K. Poustini and V. Mohammadi (2006). Evaluation of drought resistance indices under various environmental conditions. Field Crop Res. 98: 222-229.

Steel, R. G. D., J. H. Torrie and D. A. Dickey (1997). Principles and procedures of statistics. A biochemical approach, $3^{\text {rd }}$ ed. McGraw Hill Book Co. Inc., New York, USA.

Zaman, N. K., M. Y. Bdullah and S. Othman (2018). Growth and physiological performance of aerobic and lowland rice as affected by water stress at selected growth stages. Rice Science, 25 (2): 82-93.

Zubaer, M. A., A. K. B. Chowdhury, M. Z. Islam, T. Ahmed and M. A. Hasan (2007). Effects of water stress on growth and yield attributes of Aman rice genotypes. Int. J. Sustain. Crop Prod. 2(6): 25-30. 


\section{أداء بعض هجن الأرز المبشرة تحت فترات ري مختلفة}

السيد السيد جويلي، حسن شحاتة حمد، بطرس بشرى مخائيل، السيد فاروق عرفات

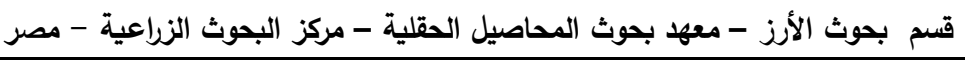

الملخص العربى

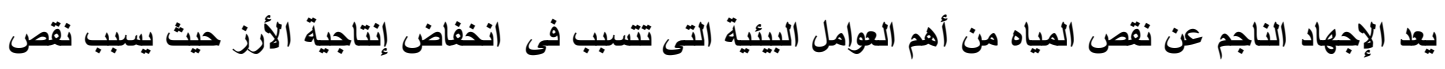

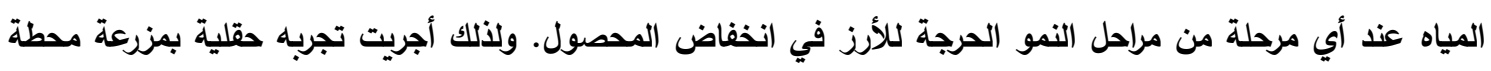

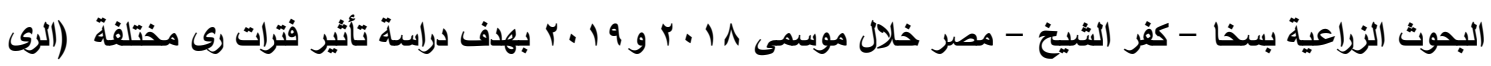

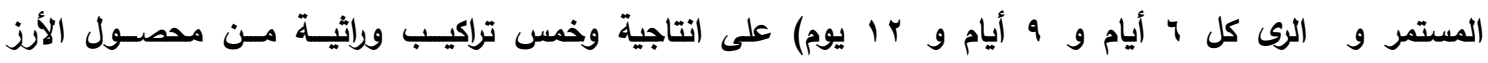

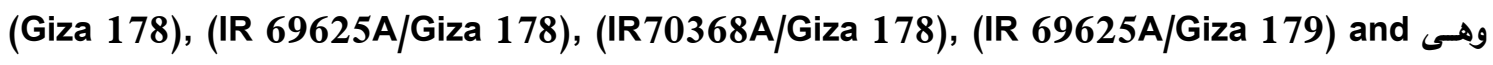
(IR 69625A/Giza 181)

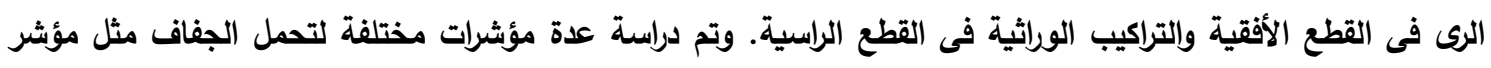

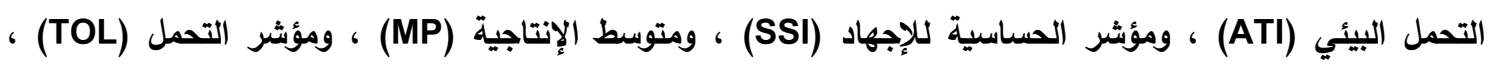

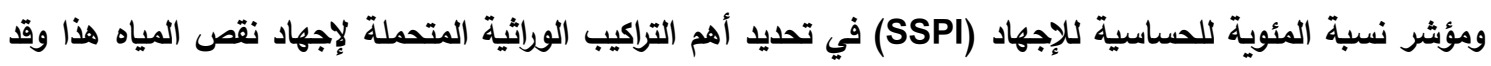

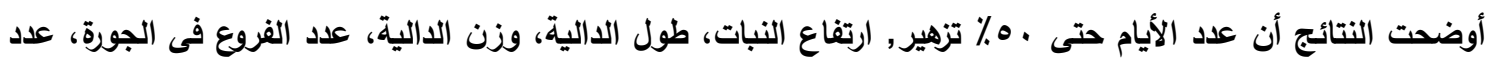

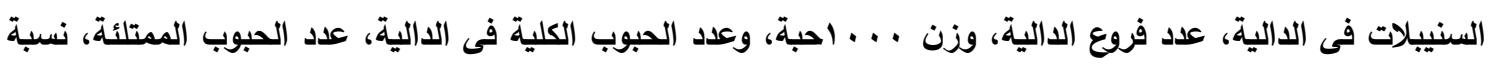

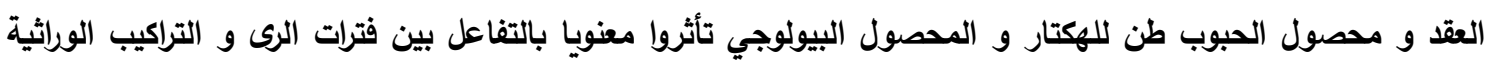

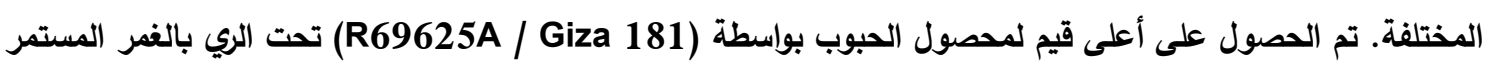

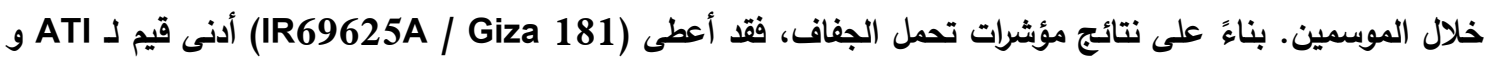

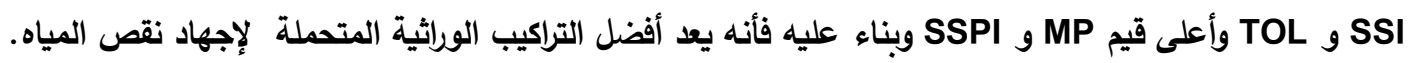

